\title{
CROSS SECTIONAL STUDY OF PREVALENCE AND RISK FACTORS OF HEPATITIS B AND HEPATITIS C INFECTION IN A RURAL VILLAGE OF INDIA
}

\author{
Prasad BHATE ${ }^{1}$, Naimish SARAF ${ }^{2}$, Pathik PARIKH ${ }^{1}$, Meghraj INGLE ${ }^{1}$, \\ Aniruddha PHADKE ${ }^{1}$ and Prabha SAWANT ${ }^{1}$
}

Received 1/5/2015

Accepted 24/6/2015

\begin{abstract}
Background - Hepatitis B virus and hepatitis C virus are among the principal causes of severe liver disease. There is limited data of epidemiology of Hepatitis B in community, more so in rural population. Objective - To find the prevalence of hepatitis B and $\mathrm{C}$ infection in community and study the risk factors for their transmission. Methods - This was a community based cross sectional study. A total of 1833 randomly selected subjects from a rural area were interviewed for risk factors for transmission and tested for markers of hepatitis B and hepatitis C infection. All the positive card tests were confirmed by ELISA. Results - Out of 2400 subjects, rate for participation was $76.38 \%$. None of the subjects was positive for anti hepatitis C virus antibody. Point prevalence for HBsAg positivity was 0.92 . Being healthcare worker and having tattoo were significantly associated with $\mathrm{HBsAg}$ positive results. Nose and ear piercing was reported by almost. History of blood or blood product transfusion, I/V drug abuse, multiple sexual partners, unsafe Injections, hemodialysis and any h/o surgery was not associated with HBsAg positivity. Conclusion - Health care workers are at high risk for transmission of hepatitis B. Educating common people regarding mode of transmission of Hepatitis $\mathrm{B}$ and $\mathrm{C}$ will help to reduce their transmission.
\end{abstract}

HEADINGS - Hepatitis B. Hepatitis C. Liver diseases. Rural population. Health personnel.

\section{INTRODUCTION}

Hepatitis B virus (HBV) and hepatitis C virus $(\mathrm{HCV})$ are among the principal causes of severe liver disease, including hepatocellular carcinoma (HCC) and cirrhosis-related end-stage liver disease ${ }^{(3)}$. Hepatitis B virus (HBV) infection is leading health problem globally. There are approximately 2 billion people infected by HBV and about 400 million carriers worldwide ${ }^{(14,15)}$. Majority of these reside in Asia and West Pacific ${ }^{(14)}$. Although HBV is present all over the world, its prevalence is significantly different across different countries ${ }^{(5)}$. An estimated $57 \%$ of cases of liver cirrhosis and $78 \%$ of cases of primary liver cancer result from $\mathrm{HBV}$ or $\mathrm{HCV}$ infection ${ }^{(9,17)}$. In terms of endemicity, India comes in Intermediate zone ${ }^{(15)}$. According to WHO, the prevalence of Hepatitis B in general population in India ranges from $0.1 \%$ to $11 \%{ }^{(11)}$, whereas various studies about epidemiology of hepatitis B in India report HBsAg seropsitivity range from $2 \%-4.7 \%{ }^{(1)}$. The reason for this heterogeneity is variation in social, economic and health factors in different regions of India ${ }^{(10)}$. Most of these studies are carried in blood donors or antenatal mothers, but there is limited data of epidemiology of hepatitis B in community $^{(15)}$ more so in rural population ${ }^{(10)}$. WHO report of hepatitis $\mathrm{C}$ suggests its prevalence $3 \%$ in the world which is a significant burden on public health ${ }^{(18)}$. hepatitis $\mathrm{C}$ is responsible of about one third of hepatocellular carcinoma ${ }^{(8)}$

Hepatitis B and hepatitis $\mathrm{C}$ share a common risk factors and common mode of transmission, so it is rationale to study prevalence of these two together. In present study, 1833 randomly selected subjects were interviewed for risk factors for transmission and tested for markers of hepatitis B and hepatitis C infection. Study population was from a village in a rural area of Western Maharashtra, India.

\footnotetext{
Declared conflict of interest of all authors: none

Disclosure of funding: no funding received

Department of Gastroenterology, Lokmanya Tilak Municipal Medical College, Sion Mumbai, India; ${ }^{2}$ Siddhakala Aurved Mahavidyalay Sangamner, Sangamner, Maharashtra, India.

Correspondence: Prasad Bhate. Dept. of Gastroenterology, First Floor, College Building, Lokmanya Tilak Municipal Medical College, Sion Mumbai Maharashtra, 400022 India. E-mail: prasadbhate07@gmail.com
} 


\section{METHODS}

This was a community based cross sectional study. The study protocol was approved by institutional ethics committee. The study was undertaken in general population of a village situated in rural area in Maharashtra state. Sample size calculation: it was calculated as 2015 on the basis of prevalence of $\mathrm{HbSAg}$ reported as $4.47 \%$. Study population was determined by electoral roll and admission register of the only school in the village. Both lists were merged together. Each person in the list was given an unique serial number. Two thousand and five hundred subjects were contacted taking into consideration the expected attrition. Two thousand and five hundred random numbers were generated by computer.

All the subjects in the sample population were approached by B.A.M.S. interns who were trained to fill the case response proforma. Written valid informed consent was taken from all the subjects (or their guardians if subject is minor). Blood sample, from the subjects who gave consent was obtained using universal sterile precautions. The samples were subjected to card test (J Mitra) for HBsAg and anti HCV antibodies. All the positive card tests were confirmed by ELISA. Considering technical difficulties in blood collection, children below 5 years of age were excluded from study. All the generated biological waste was disposed off in accordance with standard guidelines. The data was collected and compiled in excel sheet. Appropriate statistical tests (Chi square test for qualitative analysis) were used for analysis of data.

\section{RESULTS}

Out of 2400 subjects approached, 1833 agreed to participate. Response rate for participation was $76.38 \% .47 .41 \%$ of study population was male .Total 17 (8 male and 9 female) subjects were positive for HBsAg (Table 1). None of the subjects was positive for anti HCV antibody. Point prevalence for HBsAg positivity was $0.92 \%$. None of the subject's age less than 10 year (number 287) and more than 51 year was positive for HBsAg (Table 2). Being healthcare worker and having tattoo were significantly associated with $\mathrm{HBsAg}$ positive results. Nose and ear piercing was reported by almost everybody and was not significantly associated with $\mathrm{HBsAg}$ positivity. History of blood or blood product transfusion, I/V drug abuse, multiple sexual partners, unsafe Injections, hemodialysis and any h/o surgery was not associated with $\mathrm{HBsAg}$ positivity. History of male to male sex, acupuncture, organ transplant was not given by any of the participants (Table 3 ).

\section{DISCUSSION}

This study presents population based observations regarding prevalence and risk factors for transmission of hepatitis B in randomly selected rural population of Western India. Detection of HBsAg in the serum of an individual indicates that the person is currently infected with the virus. According to a metaanalysis prevalence in Indian
TABLE 1. HBsAg positive and gender distribution

\begin{tabular}{lcc}
\hline & Positive & Total \\
\hline Subjects & $17(0.9 \%)$ & 1833 \\
Males & $8(0.8 \%)$ & 869 \\
Females & $9(1.04 \%)$ & 964 \\
\hline
\end{tabular}

TABLE 2. Age distribution

\begin{tabular}{lccccc}
\hline Age group & Total N & Male & Female & Positive & \% Positive \\
\hline $5-10$ & 287 & 138 & 149 & 0 & 0 \\
$11-20$ & 404 & 175 & 229 & 7 & 1.3 \\
$21-30$ & 540 & 233 & 307 & 4 & 0.74 \\
$31-40$ & 258 & 134 & 124 & 5 & 1.98 \\
$41-50$ & 124 & 75 & 49 & 1 & 0.81 \\
$51-60$ & 116 & 55 & 61 & 0 & 0 \\
$>60$ & 104 & 58 & 46 & 0 & 0 \\
\hline
\end{tabular}

TABLE 3. Risk factors for transmission

\begin{tabular}{lccc}
\hline & $\begin{array}{c}\text { Present in } \\
\text { HBsAg positive }\end{array}$ & $\begin{array}{c}\text { Present in } \\
\text { HBsAg negative }\end{array}$ & $\boldsymbol{P}$ value \\
\hline Health care workers & 3 & 5 & 0.001 \\
Tatto & 3 & 73 & 0.03 \\
Nose or ear piercing & 16 & 1794 & 0.1150 \\
Unsafe injections & 5 & 512 & 1 \\
Any H/O surgery & 3 & 90 & 0.208 \\
$\begin{array}{l}\text { Blood or blood } \\
\text { product transfusion }\end{array}$ & 1 & 15 & 0.139 \\
I/V drug use & 0 & 4 & 1 \\
$\begin{array}{l}\text { Multiple sexual } \\
\text { partners }\end{array}$ & 0 & 10 & 1 \\
Male to male sex & 0 & 0 & 1 \\
Accupuncture & 0 & 0 & 1 \\
Hemodialysis & 0 & 3 & 1 \\
Organ transplant & 0 & 0 & 1 \\
$\begin{array}{l}\text { Institutionalized } \\
\text { persons }\end{array}$ & 0 & 0 & \\
\hline
\end{tabular}


population is not uniform. They concluded the point prevalence of hepatitis B infection in non-tribal populations is $2.4 \%$ and among tribal populations is $15.9 \% 0^{(4)}$. Our study shows much less prevalence than this finding. This indicates a decreasing trend of hepatitis B which may be because of adoption of universal immunization against hepatitis in newborns and improved living standards. HBsAg positivity was not significantly associated with any age group in our study.

Population prevalence of $\mathrm{HCV}$ infection is $1 \%$ and major route of transmission is through blood transfusion and unsterile glass syringes ${ }^{(2)}$. We did not found any subject with HVC infection in our study.

Healthcare workers are at increased risk of exposure to hepatitis B and C. Immunization against hepatitis B is recommended in healthcare workers but there is ignorance and lack of awareness regarding this ${ }^{(13)}$.

There is no vaccine available at present against hepatitis $\mathrm{C}$ infection, observance of universal precautions may protect healthcare workers. A recent study from south India concluded that the knowledge and practice of universal precaution among paramedics was unsatisfactory ${ }^{(16)}$. The risk of infection after needle-stick injury is $23 \%-62 \%$ for HBV and $0 \%-7 \%$ for $\mathrm{HCV}$ among susceptible $\mathrm{HCW}^{(12)}$.

Another study from Delhi showed that 29 of $72(40.28 \%)$ microbiology lab workers were susceptible to HBV infec$\operatorname{tion}^{(7)}$. Although guidelines are available for prevention of hepatitis B and C infection in HCWs, there is urgent need to form policies and strategies to implement these.

We found that having a tattoo was significantly associated with HBSAg seropositivity. A study of STD (sexually transmitted diseases) clinic patients in Pune mentions similar observation $^{(6)}$. Reuse of the needle without proper sterilisation may be responsible for transmission of hepatitis B. This finding emphasises need of education of masses regarding modes of transmission hepatitis B virus and its prevention. Use of disposable needles and proper sterilisation of paraphernalia may reduce transmission.

Male to male sex was not reported by any of the subjects. This may be because of the social stigma or actual low existence of such practice. Accupuncture is not common in this part of the world and was not reported by any subjects. Hemodialysis is a risk factor for both hepatitis $\mathrm{B}$ and $\mathrm{C}$ transmission. We did not found any association between lifetime history of hemodialysis and HBSAg positivity. This may be because of small number of subjects having history of hemodialysis.

None of the subjects reported history of organ transplant or institutionalisation.

There are many potential limitations to our study. First is the low participation rate of $76.36 \%$ in the study. Lack of awareness regarding the disease in general population and population based nature of the study may be the factors affecting participation. Second there is potential recall bias regarding the risk factors such as unsafe injections. Third we exclauded children less than 5 years of age because of technical difficulties expected in blood collection. This is a small portion of population and universal immunisation against hepatitis B in newborns in India may have an impact on prevalence of hepatitis B in this group. Fourth occult and cured infections could not diagnosed because other serological markers like anti hepatitis B core antibody were not tested.

\section{CONCLUSION}

Seroprevalence of HBsAg in rural population of Maharashtra was $0.92 \%$ and none of the 1833 subjects was positive for anti $\mathrm{HCV}$ antibody. Healthcare workers and having tattoo was significantly associated with $\mathrm{HBsAg}$ positivity. Educating common people regarding mode of transmission of Hepatitis B and $\mathrm{C}$ will help to reduce their transmission.

\section{Authors' contributions}

Bhate P: concept, data collection, compilation, analysis, preparation of manuscript. Saraf N: data collection, compilation, analysis. Parikh P: data analysis, preparation of manuscript. Ingle $\mathrm{M}$ : concept, preparation of manuscript, supervision. Phadke A: data collection, compilation, analysis, preparation of manuscript. Sawant P: concept, data collection, compilation, analysis, preparation of manuscript.

Bhate P, Saraf N, Parikh P, Ingle M, Phadke A, Sawant P. Prevalência e fatores de risco de infecção de hepatite B e hepatite C em uma vila rural da Índia, estudo de corte transversal. Arq Gastroenterol. 2015,52(4):xxx.

RESUMO - Contexto - O vírus da hepatite B e o vírus da hepatite C estão entre as principais causas de doença grave do fígado. Há dados limitados de epidemiologia da hepatite B na comunidade observada, mais ainda na população rural. Objetivo - Encontrar a prevalência de infecção de hepatite B e C em uma comunidade da India e pesquisar os fatores de risco para sua transmissão. Métodos - Feito estudo de corte transversal em uma comunidade. Um total de 1833 sujeitos selecionados aleatoriamente em uma área rural foram entrevistados para fatores de risco para transmissão e testados para marcadores da infecção por hepatite B e C. Todos os testes positivos de cartão foram confirmados por ELISA. Resultados - Dos 2400 pacientes objetivados houve uma taxa de participação de $76.38 \%$. Nenhum dos indivíduos foi positivo para anticorpo anti vírus da hepatite C. A prevalência pontual para a positividade do HBsAg foi de 0,92 . Ser trabalhador na área de saúde e ter tatuagem foram significativamente associados com resultados positivos de HBsAg. "Piercing" em nariz e orelha foram relatados por quase todos. História de transfusão de sangue ou uso de hemoderivados, abuso de drogas via endovenosa, múltiplos parceiros sexuais, injeções inseguras, hemodiálise e história prévia de cirurgia, não estiveram associadas à positividade do HBsAg. Conclusão - Os trabalhadores de saúde estão em alto risco para a transmissão de hepatite B. Educar pessoas comuns sobre o modo de transmissão de hepatite $\mathrm{B}$ e $\mathrm{C}$ ajudará a reduzir a sua transmissão.

DESCRITORES - Hepatitis B. Hepatite C. Hepatopatias. População rural. Pessoal de saúde. 


\section{REFERENCES}

1. Abraham P. Viral Hepatitis. India Clin Lab Med. 2012;32(2):159-74.

2. Acharya SK, Madan K, Dattagupta S, Panda SK. Viral hepatitis. India Natl Med J India. 2006;19(4):203-17

3. Baha W, Foullous A, Dersi N, They-they TP, El alaoui K, Nourichafi N, et al. Prevalence and risk factors of hepatitis $\mathrm{B}$ and $\mathrm{C}$ virus infections among the general population and blood donors in Morocco. BMC Public Health. 2013;13:50.

4. Batham A, Narula D, Toteja T, Sreenivas V, Puliyel JM. Sytematic review and meta-analysis of prevalence of hepatitis B in India. Indian Pediatr. 2007;44(9):66374.

5. Datta S. An overview of molecular epidemiology of hepatitis B virus (HBV) in India. Virol J. 2008;5:156.

6. Jagannathan L, Chaturvedi M, Mudaliar S, Kamaladoss T, Rice M, Murphy EL. Risk factors for chronic hepatitis B virus infection among blood donors in Bangalore, India. Transfus Med. 2010;20(6):414-20.

7. Jha AK, Chadha S, Bhalla P, Saini S. Hepatitis B Infection in Microbiology Laboratory Workers: Prevalence, Vaccination, and Immunity Status. Hepat Res Treat. 2012;2012:520362.

8. Parkin DM. The global health burden of infection-associated cancers in the year 2002. Int J Cancer. 2006;118(12):3030-44.

9. Perz JF, Armstrong GL, Farrington LA, Hutin YJ, Bell BP. The contributions of hepatitis $\mathrm{B}$ virus and hepatitis $\mathrm{C}$ virus infections to cirrhosis and primary liver cancer worldwide. J Hepatol. 2006;45(4):529-38.
10. Phukan P. Compliance to occupational safety measures among the paramedical workers in a tertiary hospital in Karnataka, South India. Int J Occup Environ Med. 2014;5(1):40-50.

11. Prevention of Hepatitis B in India- An Overview World Health Organization South-East Asia Regional office, New Delhi; 2002.

12. Prüss-Üstün A, Rapiti E, Hutin Y. Estimation of the global burden of disease attributable to contaminated sharps injuries among health-care workers. Am J Ind Med. 2005,48(6):482-90.

13. Reddy V, Bennadi D, Kshetrimayum N, Reddy CV, Satish G, Kura U, Yadavalli G. Prevalence of hepatitis B vaccination among oral health care personnel in Mysore city, India. Oral Health Dent Manag. 2014;13(3):652-5.

14. Robert Perrillo. Chapter 78 Hepatitis B and D. In: Befeler Sleisenger and Fordtran's Gastrointestinal and Liver Disease 2 Volume Set: Pathophysiology, Diagnosis, Management, 9th edition, Philadelphia, Elsevier, 2010.

15. Singh J, Bhatia R, Patnaik SK, Khare S, Bora D, Jain DC, Sokhey J. Community studies on hepatitis B in Rajahmundry town of Andhra Pradesh, India, 19978: unnecessary therapeutic injections are a major risk factor. Epidemiol Infec. 2000;125(2):367-75.

16. Tandon BN, Acharya SK, Tandon A. Epidemiology of hepatitis B virus infection in India. Gut. 1996;38(Suppl 2):S56-9.

17. World Health Organisation. (WHO). Hepatitis C: global prevalence. Wkly Epidemiol Rec. 1999;74(49):421-8.

18. World Health Organization (WHO). Viral hepatitis - Report by the Secretariat. [Cited 2009 November 12]. [Accessed 2012 April 25]. Available from: http://apps. who.int/gb/ebwha/pdf_files/EB126/B126_15-en.pdf 